Article

\title{
Supplemental Microalgal DHA and Astaxanthin Affect Astaxanthin Metabolism and Redox Status of Juvenile Rainbow Trout
}

\author{
Kun Wu ${ }^{1}$, Beth M. Cleveland ${ }^{2, *(D)}$, Mark Portman ${ }^{3}$, Wendy M. Sealey ${ }^{3, *}$ and Xin Gen Lei ${ }^{1, *(D)}$ \\ 1 Department of Animal Science, Cornell University, Ithaca, NY 14853, USA; kw393@cornell.edu \\ 2 USDA/ARS National Center for Cool and Cold Water Research, Leetown, WV 25430, USA \\ 3 US Fish and Wildlife Service Bozeman Fish Technology Center, Bozeman, MT 59715, USA; \\ mportman21@gmail.com \\ * Correspondence: beth.cleveland@usda.gov (B.M.C.); wendy_sealey@fws.gov (W.M.S.); \\ x120@cornell.edu (X.G.L.)
}

check for updates

Citation: Wu, K.; Cleveland, B.M.; Portman, M.; Sealey, W.M.; Lei, X.G. Supplemental Microalgal DHA and Astaxanthin Affect Astaxanthin Metabolism and Redox Status of Juvenile Rainbow Trout. Antioxidants 2021, 10, 16. https://dx.doi.org/ 10.3390/antiox10010016

Received: 30 October 2020 Accepted: 23 December 2020 Published: 27 December 2020

Publisher's Note: MDPI stays neutral with regard to jurisdictional claims in published maps and institutional affiliations.

Copyright: (C) 2020 by the authors. Licensee MDPI, Basel, Switzerland. This article is an open access article distributed under the terms and conditions of the Creative Commons Attribution (CC BY) license (https: / / creativecommons.org/ licenses/by/4.0/).

\begin{abstract}
Microalgal docosahexaenoic acid (DHA) and astaxanthin (AST) may substitute for fish oil and synthetic AST in aquafeeds. This study explored the effects and mechanisms of those substitutions on AST metabolism and redox status of rainbow trout fed plant protein meal (PM)or fishmeal (FM)-based diets. Two parallel experiments (PM vs. FM) were performed with 612 juvenile rainbow trout for 16 weeks as a $2 \times 3$ factorial arrangement of treatments with two AST sources (synthetic (SA) vs. microalgal (AA), at $80 \mathrm{mg} / \mathrm{kg}$ ) and three levels $(0,50$, and $100 \%$ ) of fish oil substitutions with DHA-rich microalgae. The fish oil substitutions exhibit main effects $(p<0.05)$ and/or interactive effects $(p<0.05)$ with the source of AST on AST deposition, malondialdehyde and glutathione concentrations, and mRNA levels and activities of major redox enzymes (glutathione reductase (GR), glutathione peroxidase (GPX), glutathione S-transferase (GST), and superoxide dismutase (SOD)) in the muscle and liver of trout fed both diet series. The AST source produced only differences in tissue AST deposition $(p<0.05)$ and number of metabolites. In conclusion, the substitutions of fish oil by the DHA-rich microalgae exerted more impacts than those of SA by AA on redox status and functional expression of antioxidant enzymes in the tissues of rainbow trout.
\end{abstract}

Keywords: algae; astaxanthin; n-3 fatty acid; redox status; trout

\section{Introduction}

Over the last decade, rapidly growing fish production has led the average consumption of fish to an annualized increase rate of $8 \%$ and this is likely to reach $22 \mathrm{~kg}$ per capita/year in 2025 [1]. Rainbow trout (Oncorhynchus mykiss) is one of the most widely cultured fish species around the world. Over 576 thousand tons of rainbow trout, valued at 2.4 billion dollars, are cultured in 69 countries [2]. Raising rainbow trout as such a vital part of the aquaculture industry relies on dietary fish oil (FO) supplementation to provide longchain polyunsaturated fatty acid (LC-PUFA) such as docosahexaenoic acid (DHA) and eicosapentaenoic acid (EPA) for ensuring the healthy growth and nutritional value of fish [3]. Shortfalls in supplies and increases in prices of FO have limited the expansion of aquaculture [4]. Meanwhile, astaxanthin (AST) is a red-orange xanthophyll carotenoid abundantly distributed in microalgae and is widely used in the food and feed industry as a pigment [5]. Currently, the most widely (over 95\%) used AST sources in animal feeds are synthesized chemically [6]. However, chemical sources of AST may have safety concerns [5,7-9] and are susceptible to degradation during storage without being embedded in a matrix with antioxidants [10].

Microalgae are rich sources of natural AST [11] and n-3 LC-PUFA [12]. There have been strong interests in using microalgae to replace FO (DHA) and synthetic AST in feeds. Indeed, microalgal oil was successfully used to replace FO in diets for rainbow trout, 
resulting in similar growth and tissue DHA deposition [13] but decreased flesh contaminant levels [14]. Our concurrent study demonstrated that the DHA-rich microalgal meal could replace up to $50 \%$ FO in diets containing synthetic AST without negative effects on growth performance and tissue fatty acid profiles of juvenile rainbow trout [15]. Microalgal AST (AA) is viewed as a suitable substitution of synthetic AST (SA) because of its excellent pigmentation efficacy and potent antioxidant capacity [7]. Sommer et al. [16] pointed out that SA led to higher AST levels in rainbow trout, whereas others demonstrated that Haematococcus microalgae had equal or superior pigmentation compared with SA [17]. However, past studies have mainly investigated singular effects of these substitutions on growth performance, flesh pigmentation, and physiological status of fish $[17,18]$. To the best of our knowledge, there is no information on the mutual effects or interactions of these substitutions on AST enrichment and metabolism in rainbow trout.

Antioxidant defenses in fish depend upon the supply and coordination of intrinsic and extrinsic antioxidants to scavenge free radicals such as reactive oxygen species (ROS) [19]. Whereas AST is a superior antioxidant that surpasses $\beta$-carotene, lutein, and even $\alpha$-tocopherol [20], DHA can be a strong pro-oxidant due to its exceptionally high unsaturation and oxidative potential in the chemical structure [21]. It remains largely unclear, in particular in fish, as to how sources and (or) concentrations of dietary DHA and AST affect the redox status and antioxidant defenses in fish. Intrinsic or endogenous antioxidant defenses include glutathione (GSH), catalase (CAT), superoxide dismutase (SOD), glutathione peroxidase (GPX), glutathione reductase (GR), and glutathione $S$-transferase (GST).

Therefore, the present study was conducted to evaluate how supplemental microalgal DHA and AST as substitutions of FO and SA affect AST metabolism and enrichment, redox status, and mRNA levels and activities of major antioxidant enzymes in the tissues of juvenile rainbow trout fed plant protein meal (PM)- or fishmeal (FM)-based diets.

\section{Materials and Methods}

\subsection{Experimental Design and Diet Preparation}

The detailed experimental design and diet formulations were presented in a concurrent study paper [15]. Briefly, two parallel 16-week feeding trials were run with a total of 612 juvenile rainbow trout assigned to 36 tanks ( 3 tanks/treatment by diet, 17 fish/tank, initial body weight $=22 \pm 0.26 \mathrm{~g}$ ). In both PM and FM diet series, a $2 \times 3$ factorial arrangement of dietary treatments was employed with 2 AST sources (at $80 \mathrm{mg} / \mathrm{kg}$, synthetic, or SA, vs. microalgal, or AA) and three levels $(0,50$, and $100 \%)$ of fish oil substitution with DHA-rich Aurantiochytrium microalgal meal (Heliae, Gilbert, AZ, USA) [19]. SA (4-ascorbyl polyphosphate Rovomix Stay-C 35; Carophyll pink) was purchased from DSM Nutritional Products Ltd. (Basel, Switzerland) and AA was from Haematococcus pluvialis (Heliae, Gilbert, AZ, USA) [19]. Fish were handled and treated in accordance with guidelines approved by the Cornell University Animal Care and Use Committee and the U.S. Fish and Wildlife Service (Protocol: Developing a new feed protein complex to replace fishmeal in fish farming, \#2017-0072, approved on 10-24-2017).

\subsection{Fish Culture and Sampling}

Rainbow trout from a single lot were obtained from a commercial producer (Troutlodge, Inc., Sumner, WA, USA), and cultured at the Bozeman Fish Technology Center (Bozeman, MT, USA). Lighting was maintained on a 13:11 h diurnal cycle. Fish were acclimated to tanks for 1 week prior to the beginning of the feeding trial. Diets were randomly assigned to three tanks $(32,200 \mathrm{~L})$ per treatment. Tanks were configured in a partial recirculating system with biofiltration, solids removal, and UV treatment of the water. Approximately $25 \%$ makeup water was added to the system daily, and water temperature was maintained at $14{ }^{\circ} \mathrm{C}$. Fish were fed to apparent satiation twice a day for 6 days a week for 16 weeks, and feed intake was determined by weighing buckets before and after feeding. Apparent satiation was defined as all the feed the fish consumed in a 30-min period. At the 
end of the study, liver and muscle samples were collected, frozen in liquid nitrogen, and then stored at $-80^{\circ} \mathrm{C}$ for the subsequent biochemical and molecular analyses.

\subsection{Astaxanthin Analysis}

Total AST in diet and tissues was extracted using a published protocol [22] with modifications. Briefly, samples of tissues (0.5-2 g) and diet (0.5-1 g) were homogenized in ethyl acetate, followed by incubation for $10 \mathrm{~min}$ on ice with vortexing periodically. Water was then added and centrifuged at $3000 \times g$ for $15 \mathrm{~min}$ at $4{ }^{\circ} \mathrm{C}$. The upper phase containing AST was collected and dried under nitrogen gas. All residues were dissolved in chloroform (HPLC-grade) and then filtered for HPLC-UV analysis. The AST concentrations were measured according to methods of Sowell et al. [23], Breithaupt et al. [24], and Rohrle et al. [25] with modifications. The AST extract was eluted with methanol and acetonitrile (50:50) containing $0.1 \%$ triethylamine (TEA) at a flow rate of $1 \mathrm{~mL} /$ minute on an Agilent Eclipse plus C18 reverse-phase column $\left(5 \mu \mathrm{m}, 4.6 \times 250 \mathrm{~mm}\right.$, at $\left.30^{\circ} \mathrm{C}\right)$ using an Agilent HPLC system with an LC-10AD micro plunger pump and an SPD-10 AV vp UV detector. The eluted peaks were identified by comparison of the retention times of standard AST (Sigma, St. Louis, MO, USA). To validate the results, sample extracts were spiked with standard AST to determine its appearance on the chromatogram in relation to the sample peak being identified. The AST concentrations were calculated by the areas under the curves (AUCs) of the samples against those of the spiked AST standard in the chromatograms. The extraction efficiency (recovery) of AST was $92 \%$.

\subsection{Determination of Antioxidant/Oxidant Biomarkers}

Malondialdehyde (MDA) determination was based on the reaction of thiobarbituric acid (TBA) with MDA and the formation of fluorescing (excitation/emission 520/550 nm) MDA-(TBA $)_{2}$ adducts. Glutathione determination was based on the reaction of GSH with DTNB [5,5-dithiobis(2-nitrobenzoic acid)] to form GSSG (glutathione disulfide) and 5-thionitrobenzoic acid (TNB), which was detected spectrophotometrically at $412 \mathrm{~nm}[19,26]$. Activities of GST, GPX, GR, and SOD were measured in the muscle (fillet) and liver tissues using methods described in previous studies [27-30]. Briefly, GST activity was determined by measuring the formation of the conjugate of GSH and 1-chloro-2,4-dinitrobenzene (CDNB). GPX activity was determined spectrophotometrically at $340 \mathrm{~nm}$ by coupling the recycling of GSH with the oxidation of NADPH under the catalysis of GR. GR activity was determined by measuring the rate of NADPH oxidation used for reducing GSSG at $340 \mathrm{~nm}$. SOD activity was measured by a spectrophotometric method $(470 \mathrm{~nm})$ based on the inhibition of XTT ( $3^{\prime}-\{1-[($ Phenylamino)-carbonyl]-3,4-tetrazolium\}-bis(4-methoxy6-nitro)benzenesulphonic acid hydrate) reduction by superoxide anions generated by xanthine-xanthine oxidase.

\subsection{Gene Expression}

Total RNA of the liver was extracted using TRIzol reagent (Millipore-Sigma, St. Louis, MO, USA) according to the manufacturer's protocol. Quantitative real-time PCR (qPCR) was performed using an ABI Vii 7 Detection System (Applied Biosystems, Foster City, CA, USA) using SYBR Green supermix (Bio-Rad, Hercules, CA, USA). The reaction volume was $20 \mu \mathrm{L}$, which contained $1 \mu \mathrm{L}$ 10-fold dilution of cDNA (complementary DNA), $10 \mu \mathrm{L}$ SYBR Green supermix, $10 \mathrm{mM}$ each of forward and reverse primers (Table S1), and 0.4 and $8.2 \mu \mathrm{L} \mathrm{H}_{2} \mathrm{O}$. The qPCR protocol consisted of initial denaturation at $95^{\circ} \mathrm{C}$ for $30 \mathrm{~s}$, followed by 40 cycles at $95^{\circ} \mathrm{C}$ for $5 \mathrm{~s}$, and $60^{\circ} \mathrm{C}$ for $60 \mathrm{~s}$. Real-time qPCR data were analyzed using the standard curve approach after normalizing to beta-actin and elf1a (elongation factor 1a) as reference genes.

\subsection{Statistical Analysis}

Because of the main objectives of the present study and the ingredient differences and the resultant impact on the responses to treatments, we analyzed the data from the 
PM and FM diet series separately. Within each diet series, a two-way ANOVA (analysis of variance) ( 2 by 3 factorial arrangement of dietary treatments) was used to evaluate the main effects of AST source (SA vs. AA), fish oil substitution levels (0, 50, and 100\%), and their interactions. Duncan's multiple range test was used to compare the treatment mean differences. Pearson's correlation was calculated to examine the relationship between AST concentration and MDA, GSH, and enzyme activities within tissues. Three types of stepwise regression analyses were performed to rank the importance of the assumed independent variables such as tissue AST concentration in regulating the responses of assumed dependent variables such as tissue MDA or GSH or activity of redox enzymes. Data are presented as means \pm SEM (standard error of mean), and the significance level is $p<0.05$.

\section{Results}

Detailed composition and analytic nutrient values including DHA concentrations of experimental diets were reported in the concurrent study paper [15]. Effects of the FO and SA substitutions on growth performance, body condition indices, tissue lipid and fatty acid profiles, and gene expression related to growth and biosynthesis of LC-PUFA were presented in that paper. Notably, the $100 \%$ FO oil replacement impaired growth performance, dietary protein and energy utilization, body indices, and tissue accumulation of DHA and EPA in both diet series. Overall, replacing FO with DHA-rich microalgae produced more negative metabolic responses than the substitution of SA by AA in fish fed both PM and FM diet series.

\subsection{Concentrations of Astaxanthin in Diets and Tissues}

In both the PM and FM diet series, the SA diets had $>$ five-fold higher $(p<0.05)$ concentrations of AST than those of AA (Table 1). Consequently, similar differences $(p<0.05)$ between SA and AA diets were shown in both liver and muscle accumulations of AST (Figure 1). Within a given source of AST, there was a progressive reduction $(p<0.05)$ in liver and muscle AST concentrations with increasing levels of FO substitution with the DHA-rich microalgae, although the magnitudes of the decreases varied with the treatment combination and tissue type. Fish fed the PM diets supplemented with SA and $0 \%$ FO substitution had the highest AST accumulations, reaching $4.8 \mu \mathrm{g} / \mathrm{g}$ of the muscle and $0.5 \mu \mathrm{g} / \mathrm{g}$ of the liver.
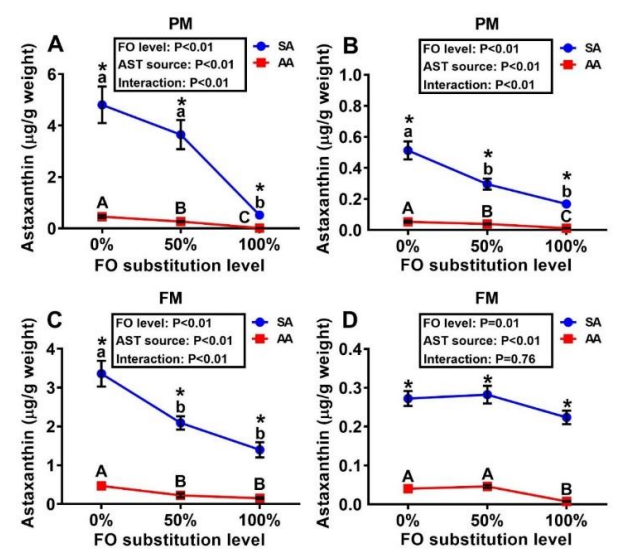

Figure 1. Effects of dietary fish oil (FO) substitution by docosahexaenoic acid (DHA)-rich microalgae and source of astaxanthin (AST) on astaxanthin concentrations in the muscle (fillet, $\mathbf{A}, \mathbf{C}$ ) and liver (B,D) of juvenile rainbow trout fed the plant meal- (PM, A,B) and fishmeal (FM, C,D)-based diets. Means labelled with different letters [lowercase $(a, b)$, synthetic astaxanthin (SA) groups; uppercase $(\mathrm{A}-\mathrm{C})$, microalgae astaxanthin (AA) groups] are different between various fish oil substitutions $(p<0.05)$. Asterisks $\left(^{*}\right)$ indicate differences between SA and AA groups $(p<0.05)$ at the same level of FO substitution. FO: fish oil. AST: astaxanthin. 
Table 1. Analyzed concentrations of astaxanthin in experimental diets ${ }^{1}$.

\begin{tabular}{|c|c|c|c|c|c|c|c|}
\hline \multirow{3}{*}{$\begin{array}{c}\text { Fish Oil Replacement Level }{ }^{2} \\
\text { Astaxanthin Source }^{3}\end{array}$} & \multicolumn{7}{|c|}{ Diets } \\
\hline & \multicolumn{2}{|c|}{$0 \%$} & \multicolumn{2}{|c|}{$50 \%$} & \multicolumn{2}{|c|}{$100 \%$} & \multirow{2}{*}{ SEM } \\
\hline & SA & AA & SA & AA & SA & AA & \\
\hline \multicolumn{8}{|c|}{ Plant meal-based diet } \\
\hline Astaxanthin ( $\mu \mathrm{g} / \mathrm{g}$ diet$)$ & $42^{\mathrm{a}}$ & $6.7^{\mathrm{b}}$ & $33^{a}$ & $7.1^{b}$ & $32^{a}$ & $4.1^{b}$ & 0.39 \\
\hline \multicolumn{8}{|c|}{ Fishmeal-based diet } \\
\hline Astaxanthin ( $\mu \mathrm{g} / \mathrm{g}$ diet$)$ & $41^{\mathrm{a}}$ & $5.8^{b}$ & $37^{\mathrm{a}}$ & $5.1^{\mathrm{b}}$ & $28^{a}$ & $4.0^{\mathrm{b}}$ & 0.42 \\
\hline
\end{tabular}

${ }^{1}$ Values of means $(n=3) ;{ }^{2}$ Percent of DHA-rich microalgae (Aurantiochytrium, Heliae, Gilbert, AZ, USA) to replace menhaden fish oil (Omega Protein, Houma, LA, USA); ${ }^{3}$ SA: synthetic astaxanthin, 4-ascorbyl polyphosphate Rovomix Stay-C 35; Carophyll pink (DSM Nutritional Products Ltd., Basel, Switzerland); AA: microalgal astaxanthin, Haematococcus pluvialis, (Heliae, Gilbert, AZ, USA). Means labelled with different letters $(a, b)$ are different between various diets within the same series $(p<0.05)$.

\subsection{Metabolites of Astaxanthin in the Liver and Muscle}

Only a single peak of AST (retention time: $3.8 \mathrm{~min}$ ) was found in the HPLC chromatogram profiles of muscle samples from all treatment groups. In comparison, three peaks (retention times: 1.8, 2.3, and $4.5 \mathrm{~min}$ ), in addition to the same peak shown in the muscle, were observed in the liver samples (Figure 2). These peaks presumably represented different metabolites of AST. The 1.8 min peak area was decreased $(p<0.05)$ by the $100 \%$ FO substitution in the SA diets of both PM and FM series (Figure 2A,B). The AA diets resulted in greater $(p<0.05) 2.3$ min peak areas than those of SA in both PM and FM series (Figure 2C,D). Intriguingly, this peak area was enhanced $(p<0.05)$ in the liver of fish by $100 \%$ FO substitution over the $0 \%$ or $50 \%$ FO substitution in the AA diets of FM series (Figure 2D). The SA diets led to greater $(p<0.05)$ areas of the 4.5 min peak than the AA diets in both PM and FM series, and the $100 \%$ FO substitution decreased $(p<0.05)$ the area of this peak compared with the other two levels of FO substitution (Figure 2E,F). Responses of the total areas of the three peaks to the treatments seemed to be similar to those of the 2.3 min peak (Figure 2G,H). Overall, both the AST source and the FO substitution exhibited main effects $(p<0.01)$, but no interactions (except for the 1.8 min peak), on the areas of these peaks either singularly or together in the PM series. In contrast, the AST source and the FO substitution demonstrated not only main effects $(p<0.01)$ but also interactions $(p<0.01)$ on the areas of all these peaks in the FM series.

\subsection{Tissue MDA and GSH Concentrations and Antioxidant Enzyme Activities}

There were dose-dependent elevations in the liver MDA concentrations with increasing levels of FO substitution in the fish fed the SA diets of both PM and FM series (Figure $3 \mathrm{~B}, \mathrm{D}$ ), whereas the muscle MDA concentrations remained similar across the dietary treatments (Figure $3 \mathrm{~A}, \mathrm{C}$ ). Muscle GSH concentrations in the fish fed the FM diet series were decreased $(p<0.05)$ by the $50 \%$ and $100 \%$ substitutions of FO over the $0 \%$ substitution (Figure $4 \mathrm{C}$ ). In fish fed the PM diet series, the FO substitutions resulted in dose-dependent activity decreases $(p<0.05)$ of all four assayed enzymes in both muscle and liver, except for muscle GPX and liver GR activities (Table 2). In contrast, the AST source exerted a main effect $(p<0.05)$ on only liver GST activity, in which the SA supplementation led to lower $(p<0.05)$ hepatic GST activities than that with AA at both $0 \%$ and $50 \%$ FO substitutions. In fish fed the FM diet series, activities of the four assayed enzymes were not altered in the muscle by the dietary treatments. In contrast, hepatic activities of these enzymes were affected $(p<0.05)$ by the FO substitutions, the AST source, and (or) their interactions. In general, $50 \%$ and (or) $100 \%$ FO substitution decreased $(p<0.05)$ the activities more than the $0 \%$ substitution, whereas SA produced higher $(p<0.05)$ activity levels than AA with a couple of exceptions. 

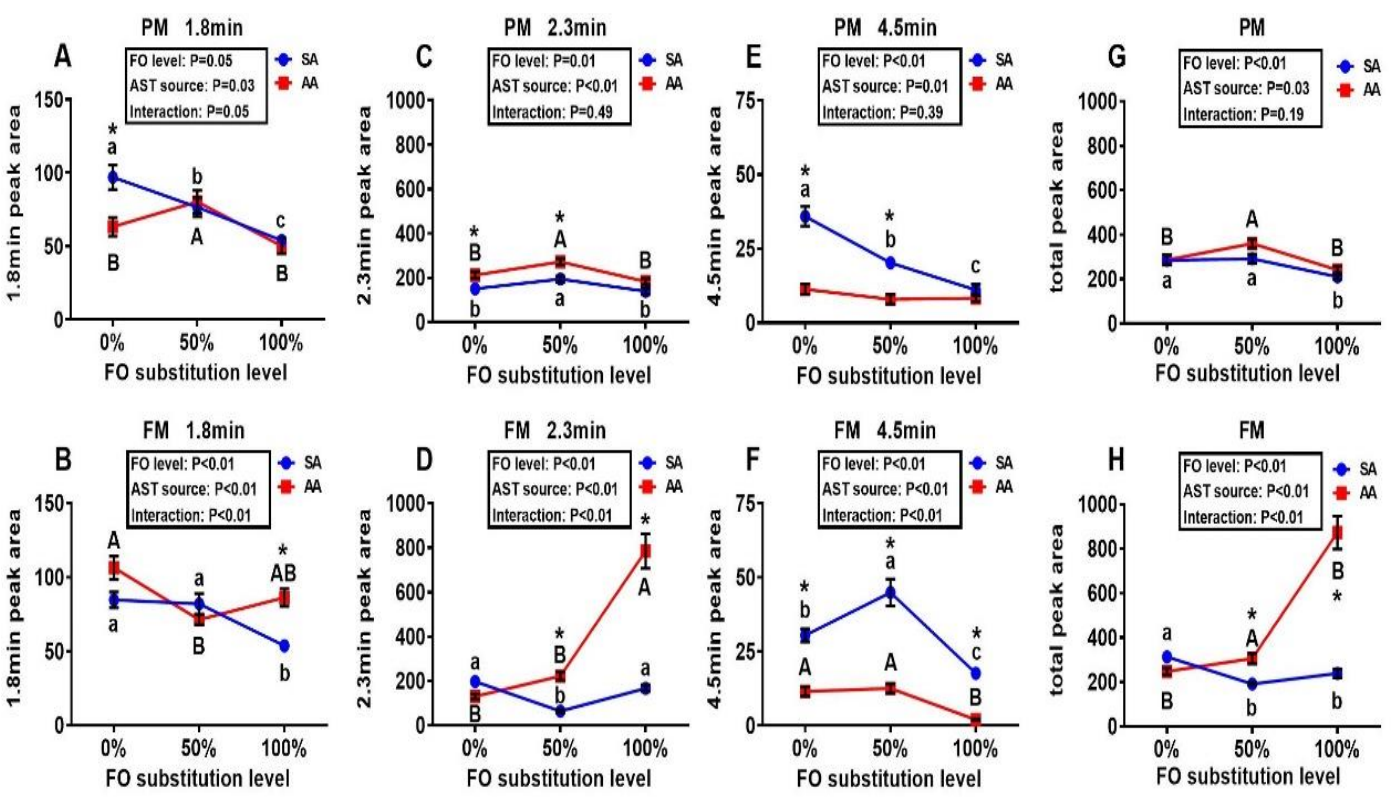

Figure 2. Effects of dietary fish oil substitution by DHA-rich microalgae and source of astaxanthin on relative areas of hepatic astaxanthin metabolite peaks (A,B: $1.8 \mathrm{~min}$; C,D: $2.3 \mathrm{~min}$; E,F: $4.5 \mathrm{~min}$; G,H: total of the three peaks) in juvenile rainbow trout fed the plant meal- (PM, A,C,E,G) and fishmeal (FM, B,D,F,H)-based diets. Means labelled withdifferent letters [lowercase $(\mathrm{a}, \mathrm{b})$, synthetic astaxanthin (SA) groups; uppercase (A, B), microalgae astaxanthin (AA) groups] are different between various levels of fish oil substitution $(p<0.05)$. Asterisks $\left(^{*}\right)$ indicate differences between SA and AA groups $(p<0.05)$ at the same level of FO substitution. The absence of different letters $\left(\mathrm{a}, \mathrm{b}, \mathrm{c}\right.$ or A, B) or asterisks $\left({ }^{*}\right)$ between means indicates no significant differences. FO: fish oil. AST: astaxanthin.
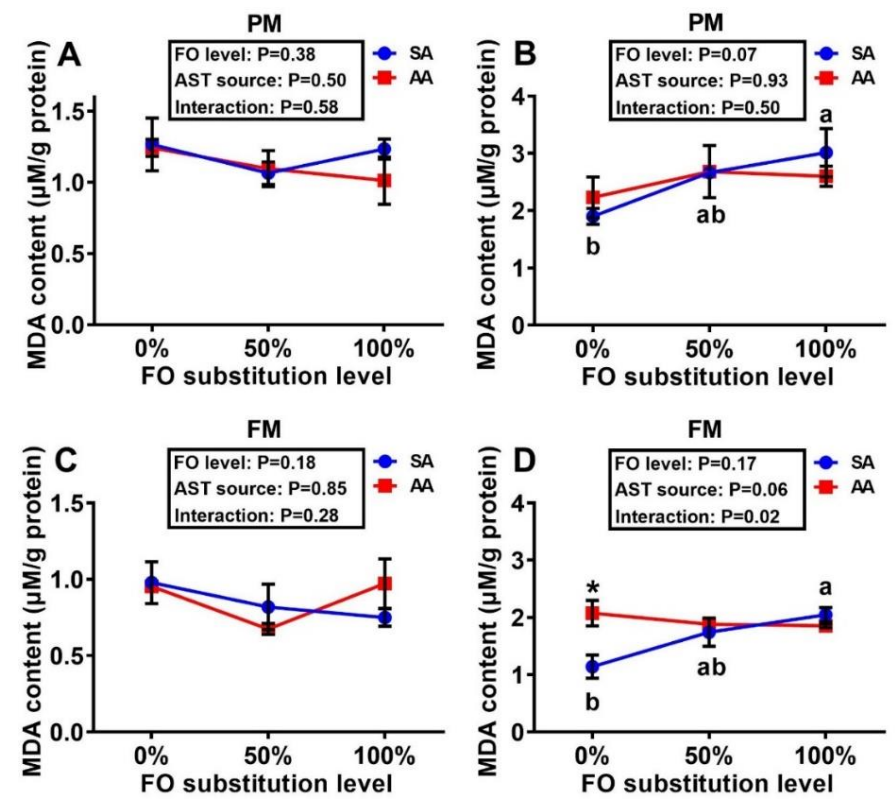

Figure 3. Effects of dietary fish oil substitution by DHA-rich microalgae and source of astaxanthin on MDA concentrations in the muscle (fillet, $\mathbf{A}, \mathbf{C}$ ) and liver $(\mathbf{B}, \mathbf{D})$ of juvenile rainbow trout fed the plant meal- (PM, A,B) and fishmeal (FM, C,D)-based diets. Means labelled with different letters [lowercase $(a, b)$, synthetic astaxanthin (SA) groups] are different between various fish oil substitutions $(p<0.05)$. Asterisks $\left(^{*}\right)$ indicate differences between the SA and AA groups $(p<0.05)$ at the same level of FO substitution. The absence of different letters $(a, b)$ or asterisks $\left(^{*}\right)$ between means indicates no significant differences. MDA: malondialdehyde. FO: fish oil. AST: astaxanthin. 

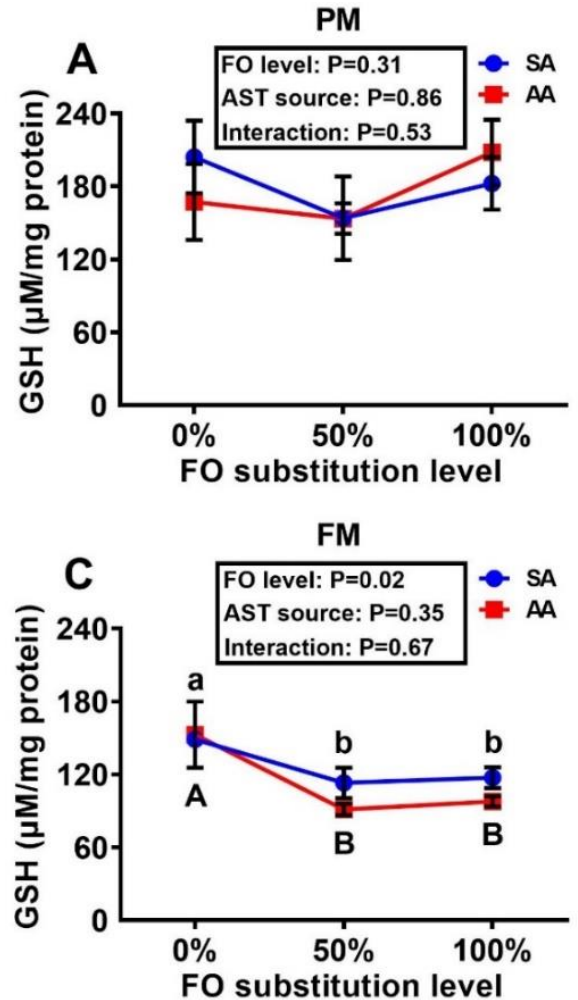
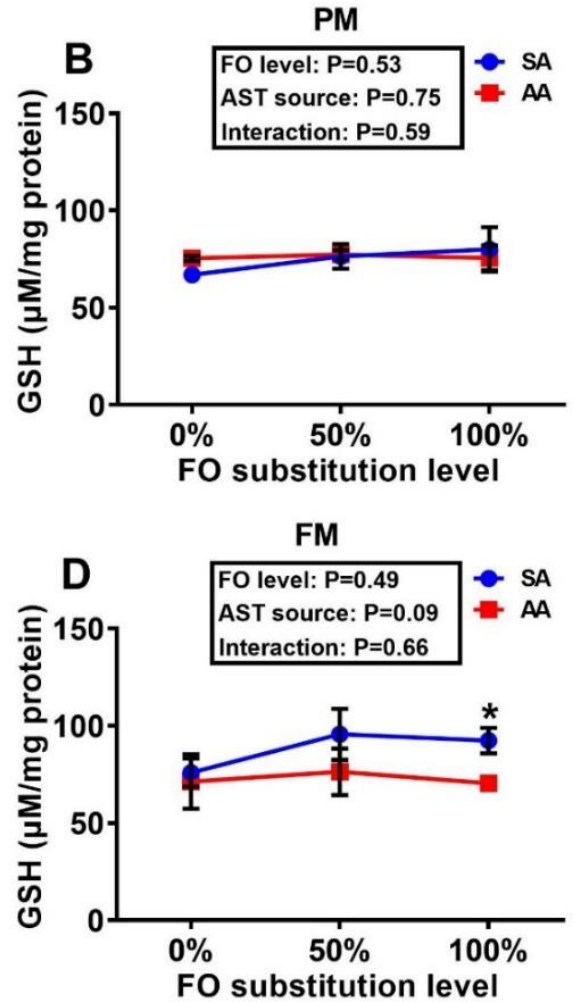

Figure 4. Effects of dietary fish oil substitution by DHA-rich microalgae and source of astaxanthin on GSH concentrations in the muscle (fillet, $\mathbf{A}, \mathbf{C}$ ) and liver $(\mathbf{B}, \mathbf{D})$ of juvenile rainbow trout fed the plant meal- (PM, A,B) and fishmeal (FM, C,D)-based diets. Means labelled with different letters [lowercase $(a, b)$, synthetic astaxanthin (SA) groups; uppercase (A, B), microalgae astaxanthin (AA) groups] are different between various fish oil substitutions $(p<0.05)$. Asterisks $\left(^{*}\right)$ indicate differences between the SA and AA groups $(p<0.05)$ at the same level of FO substitution. The absence of different letters $\left(\mathrm{a}, \mathrm{b}\right.$ or A, B) or asterisks $\left(^{*}\right)$ between means indicates no significant differences. GSH: glutathione. FO: fish oil. AST: astaxanthin.

\subsection{Antioxidant Enzyme Gene Expressions}

Expression of SOD1 was similar across treatment groups, with the exception of the PMAA diet series in which the $50 \%$ FO substitution led to greater $(p<0.05)$ SOD1 expression than the $0 \%$ or $100 \%$ FO substitutions (Figure $5 \mathrm{~A}, \mathrm{~B}$ ). The $100 \%$ FO substitution decreased $(p<0.05)$ hepatic expression of SOD2 more than the $0 \%$ and $50 \%$ FO substitutions in the PM-AA diet series. At $50 \%$ FO substitution, AA produced greater $(p<0.05)$ hepatic mRNA levels of SOD2 than SA. In the FM-SA diet series, the $50 \%$ FO substitution induced higher $(p<0.05)$ expression of SOD2 than that of $0 \%$ or $100 \%$ substitution (Figure $5 C, D)$. In both the FM and PM diet series, the FO substitutions produced dose-dependent positive effects on the expression of hepatic GPX1a regardless of the AST source (Figure 6A,B). Neither the FO substitution nor the AST source had main effects on the expressions of liver GPX1b1 (Figure 6C,D), although a main effect of FO substitution on hepatic GPX1b2 expression occurred in the PM diet series (Figure $6 \mathrm{E}, \mathrm{F})$. Main effects $(p<0.05)$ of FO substitution occurred on hepatic CAT expression in both the PM and FM diet series, in which lower $(p<0.05)$ expression levels were shown in the $100 \%$ than the $0 \%$ and $50 \%$ FO substitution groups of the PM-AA and FM-SA series (Figure 7A,B). Main effects $(p<0.05)$ of the FO substitution also occurred on hepatic GR expression. In the PM-SA diet series, the GR expression was elevated $(p<0.05)$ by the $50 \%$ than the $0 \%$ FO substitution, whereas the expression was decreased $(p<0.05)$ by the $100 \%$ than the $50 \%$ FO substitution in the FM-AA diet series (Figure 7C,D). In the PM diet series, hepatic GST expression was greater $(p<0.05)$ with $50 \%$ rather than $0 \%$ or $100 \%$ FO substitution, regardless of the AST source (Figure 7E,F). In the FM diet series, hepatic GST expression was much lower $(p<0.0001)$ 
with $100 \%$ rather than $0 \%$ or $50 \%$ FO substitution, irrespective of the AST source. Notably, the AST source failed to show main effects on the hepatic expression of any of the eight genes assayed.

Table 2. Effects of dietary fish oil substitution by DHA-rich microalgae and source of astaxanthin on antioxidant enzyme activities in the muscle (fillet) and liver of juvenile rainbow trout.

\begin{tabular}{|c|c|c|c|c|c|c|c|c|c|c|}
\hline \multirow{3}{*}{$\begin{array}{c}\text { Fish Oil Replacement Level }^{1} \\
\text { Astaxanthin Source }^{2}\end{array}$} & \multicolumn{6}{|c|}{ Diets } & \multicolumn{4}{|c|}{$p$ Value } \\
\hline & \multicolumn{2}{|c|}{$0 \%$} & \multicolumn{2}{|c|}{$50 \%$} & \multicolumn{2}{|c|}{$100 \%$} & \multirow{2}{*}{$\begin{array}{c}\text { FO } \\
\text { Level }\end{array}$} & \multirow{2}{*}{$\begin{array}{l}\text { AST } \\
\text { Source }\end{array}$} & \multirow{2}{*}{ Interaction } & \multirow[b]{2}{*}{ SEM } \\
\hline & SA & AA & SA & AA & SA & AA & & & & \\
\hline \multicolumn{11}{|c|}{ Plant Meal-Based Diet } \\
\hline & & & & Muscle & & & & & & \\
\hline $\mathrm{GST}^{3}(\mathrm{mU} / \mathrm{mg}$ protein) & $0.81^{\mathrm{a}, \mathrm{b}}$ & $1.1^{\mathrm{a}}$ & $0.90^{\mathrm{a}}$ & $0.85^{\mathrm{a}, \mathrm{b}}$ & $0.72^{a, b}$ & $0.54^{\mathrm{b}}$ & 0.03 & 0.90 & 0.15 & 0.05 \\
\hline GPX (mU/mg protein) & $2.9^{\mathrm{a}, \mathrm{b}}$ & $3.4^{\mathrm{a}}$ & $2.1^{b}$ & $2.9^{a, b}$ & $2.3^{\mathrm{a}, \mathrm{b}}$ & $2.5^{\mathrm{a}, \mathrm{b}}$ & 0.15 & 0.11 & 0.71 & 0.16 \\
\hline GR (mU/mg protein) & $0.26^{a, b}$ & $0.32^{\mathrm{a}}$ & $0.19^{b}$ & $0.24^{\mathrm{a}, \mathrm{b}}$ & $0.18^{\mathrm{b}}$ & $0.20^{\mathrm{b}}$ & 0.02 & 0.13 & 0.71 & 0.02 \\
\hline $\mathrm{SOD}(\mathrm{mU} / \mathrm{mg}$ protein) & $23^{a}$ & $24^{\mathrm{a}}$ & $19^{\mathrm{a}, \mathrm{b}}$ & $24^{\mathrm{a}}$ & $16^{\mathrm{a}, \mathrm{b}}$ & $12^{\mathrm{b}}$ & 0.01 & 0.92 & 0.29 & 1.4 \\
\hline \multicolumn{11}{|c|}{ Liver } \\
\hline GST (mU/mg protein) & $4.6^{\mathrm{a}, \mathrm{b}, \mathrm{c}}$ & $5.7^{a, b}$ & $4.4^{\mathrm{b}, \mathrm{c}}$ & $6.1^{\mathrm{a}}$ & $3.9^{c}$ & $3.9^{c}$ & 0.03 & 0.04 & 0.24 & 0.26 \\
\hline GPX (mU/mg protein) & $13^{\mathrm{a}, \mathrm{b}}$ & $16^{\mathrm{a}}$ & $16^{\mathrm{a}}$ & $14^{\mathrm{a}, \mathrm{b}}$ & $11^{\mathrm{b}}$ & $12^{\mathrm{a}, \mathrm{b}}$ & 0.04 & 0.50 & 0.22 & 0.62 \\
\hline $\mathrm{GR}$ (mU/mg protein) & 2.5 & 2.0 & 2.7 & 3.2 & 2.5 & 2.6 & 0.19 & 0.85 & 0.38 & 0.15 \\
\hline $\mathrm{SOD}(\mathrm{mU} / \mathrm{mg}$ protein) & $139^{\mathrm{a}, \mathrm{b}}$ & $143^{\mathrm{a}}$ & $99.0^{b, c}$ & $120^{a, b, c}$ & $88.0^{\mathrm{c}}$ & $105^{a, b, c}$ & 0.01 & 0.22 & 0.80 & 6.64 \\
\hline \multicolumn{11}{|c|}{ Fishmeal-Based Diet } \\
\hline \multicolumn{11}{|c|}{ Muscle } \\
\hline GST (mU/mg protein) & 1.0 & 1.1 & 0.85 & 0.84 & 0.84 & 0.86 & 0.03 & 0.89 & 0.95 & 0.04 \\
\hline GPX (mU/mg protein) & 2.4 & 2.4 & 2.5 & 1.7 & 2.8 & 2.3 & 0.15 & 0.11 & 0.71 & 0.14 \\
\hline $\mathrm{GR}(\mathrm{mU} / \mathrm{mg}$ protein) & 0.26 & 0.21 & 0.23 & 0.18 & 0.16 & 0.21 & 0.49 & 0.77 & 0.15 & 0.01 \\
\hline $\mathrm{SOD}(\mathrm{mU} / \mathrm{mg}$ protein) & 26 & 14 & 16 & 21 & 22 & 19 & 0.78 & 0.25 & 0.10 & 1.54 \\
\hline \multicolumn{11}{|c|}{ Liver } \\
\hline GST (mU/mg protein) & $5.2^{\mathrm{a}}$ & $4.0^{\mathrm{a}, \mathrm{b}}$ & $2.2^{b}$ & $2.2^{b}$ & $3.7^{a, b}$ & $3.1^{b}$ & 0.01 & 0.24 & 0.61 & 0.31 \\
\hline GPX (mU/mg protein) & $14^{\mathrm{a}}$ & $15^{\mathrm{a}}$ & $15^{\mathrm{a}}$ & $9.3^{b}$ & $9.8^{\mathrm{b}}$ & $5.3^{c}$ & $<0.001$ & 0.01 & 0.04 & 0.98 \\
\hline $\mathrm{GR}$ (mU/mg protein) & $2.8^{\mathrm{b}, \mathrm{c}}$ & $4.0^{\mathrm{a}}$ & $3.6^{\mathrm{a}, \mathrm{b}}$ & $2.3^{c}$ & $2.8^{\mathrm{b}, \mathrm{c}}$ & $2.3^{c}$ & 0.03 & 0.24 & 0.01 & 0.18 \\
\hline $\mathrm{SOD}(\mathrm{mU} / \mathrm{mg}$ protein) & $61^{b, c}$ & $96^{\mathrm{a}}$ & $92^{\mathrm{a}}$ & $86^{a, b}$ & $56^{\mathrm{c}}$ & $36^{c}$ & 0.01 & 0.66 & 0.02 & 5.99 \\
\hline
\end{tabular}

${ }^{1}$ Percent of DHA-rich microalgae (Aurantiochytrium, Heliae, Gilbert, AZ, USA) to replace menhaden fish oil (Omega Protein, Houma, LA, USA). ${ }^{2}$ SA: synthetic astaxanthin, 4-ascorbyl polyphosphate Rovomix Stay-C 35; Carophyll pink (DSM Nutritional Products Ltd., Basel, Switzerland); AA: microalgal astaxanthin, Haematococcus pluvialis, (Heliae, Gilbert, AZ, USA). ${ }^{3}$ GST: Glutathione S-transferase; GPX: Glutathione peroxidase; GR: Glutathione reductase; SOD: Superoxidase dismutase. ${ }^{\mathrm{a}}, \mathrm{b},{ }^{\mathrm{c}}$ Values are means $(n=3)$, and means in the same row without a common letter differ $(p<0.05)$.

\subsection{Correlation Analyses}

In the PM-AA diet series, there were strong positive correlations $(\mathrm{R}>0.74, p<0.05)$ between the AST concentrations and activities of GST, GR, and SOD in the muscle (Table S2). In the FM-SA diet series, there was a strong postivie correlation $(R=0.70, p<0.05)$ between the muscle AST and GSH concentrations. Liver AST concentrations were negatively correlated with the MDA concentrations $(R=-0.83, p<0.05)$, but positively associated with SOD activity $(R=0.82, p<0.05)$ in the PM-SA diet series. There was a positive correlation $(R=0.87, p<0.05)$ between the liver AST concentrations and GST activities in the PM-AA diet series. There were positive correlations between the liver AST concentrations and GPX $(R=0.67, p<0.05)$ and SOD $(R=0.90, p<0.05)$ activities in the FM-AA series. 

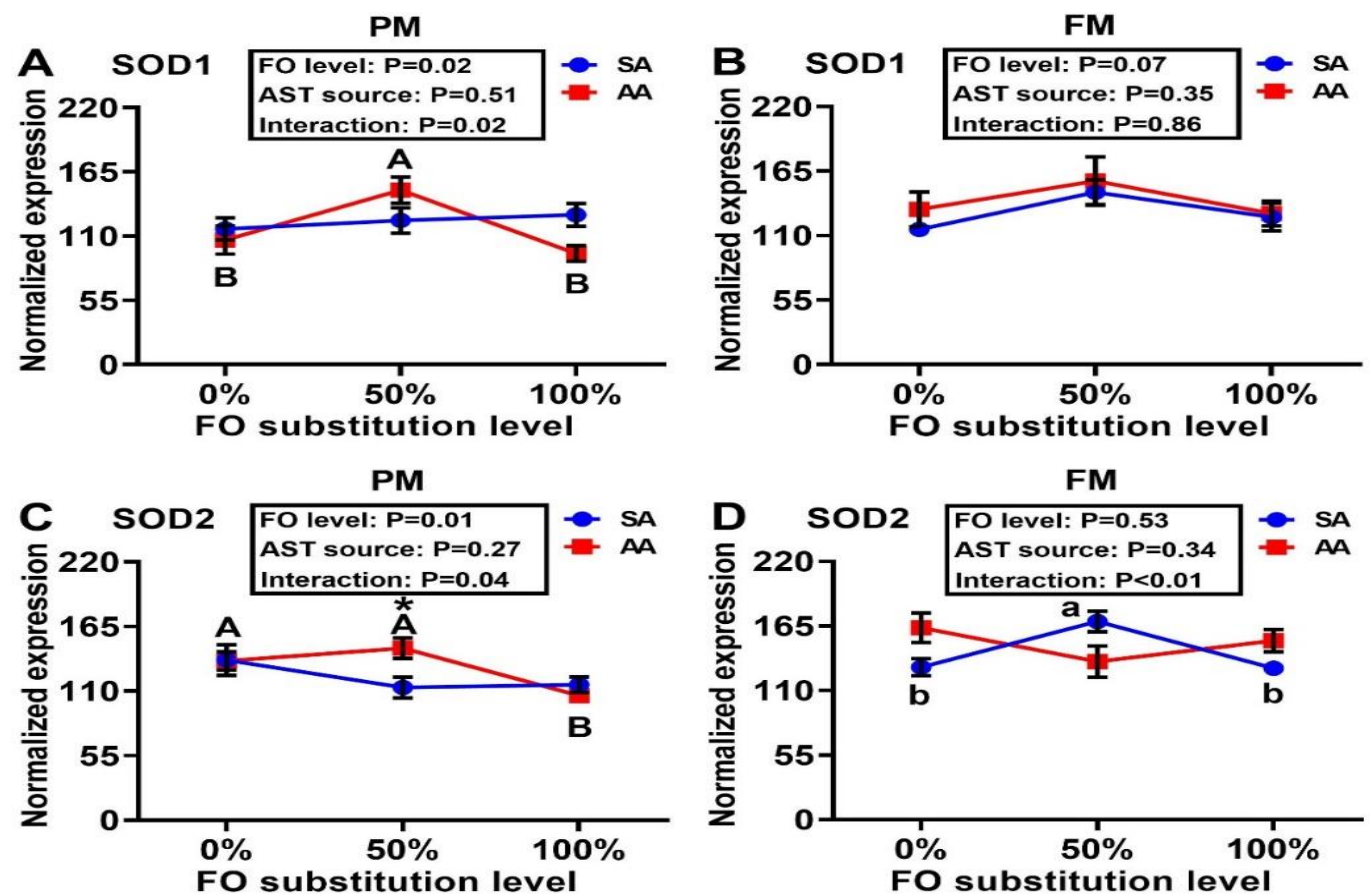

Figure 5. Effects of dietary fish oil substitution by DHA-rich microalgae and source of astaxanthin on hepatic mRNA levels of SOD1 (A,B) and SOD2 (C,D) of juvenile rainbow trout fed the plant meal- (PM, A,C) and fishmeal (FM, B,D)-based diets. Means labelled with different letters [lowercase $(a, b)$, synthetic astaxanthin (SA) groups; uppercase (A, B), microalgae astaxanthin (AA) groups] are different between various fish oil substitutions $(p<0.05)$. Asterisks $\left(^{*}\right)$ indicate differences between SA and AA groups $(p<0.05)$ at the same level of FO substitution. The absence of different letters $(\mathrm{a}, \mathrm{b}$ or A, B) or asterisks $\left(^{*}\right)$ between means indicates no significant differences. SOD: superoxide dismutase. FO: fish oil. AST: astaxanthin.
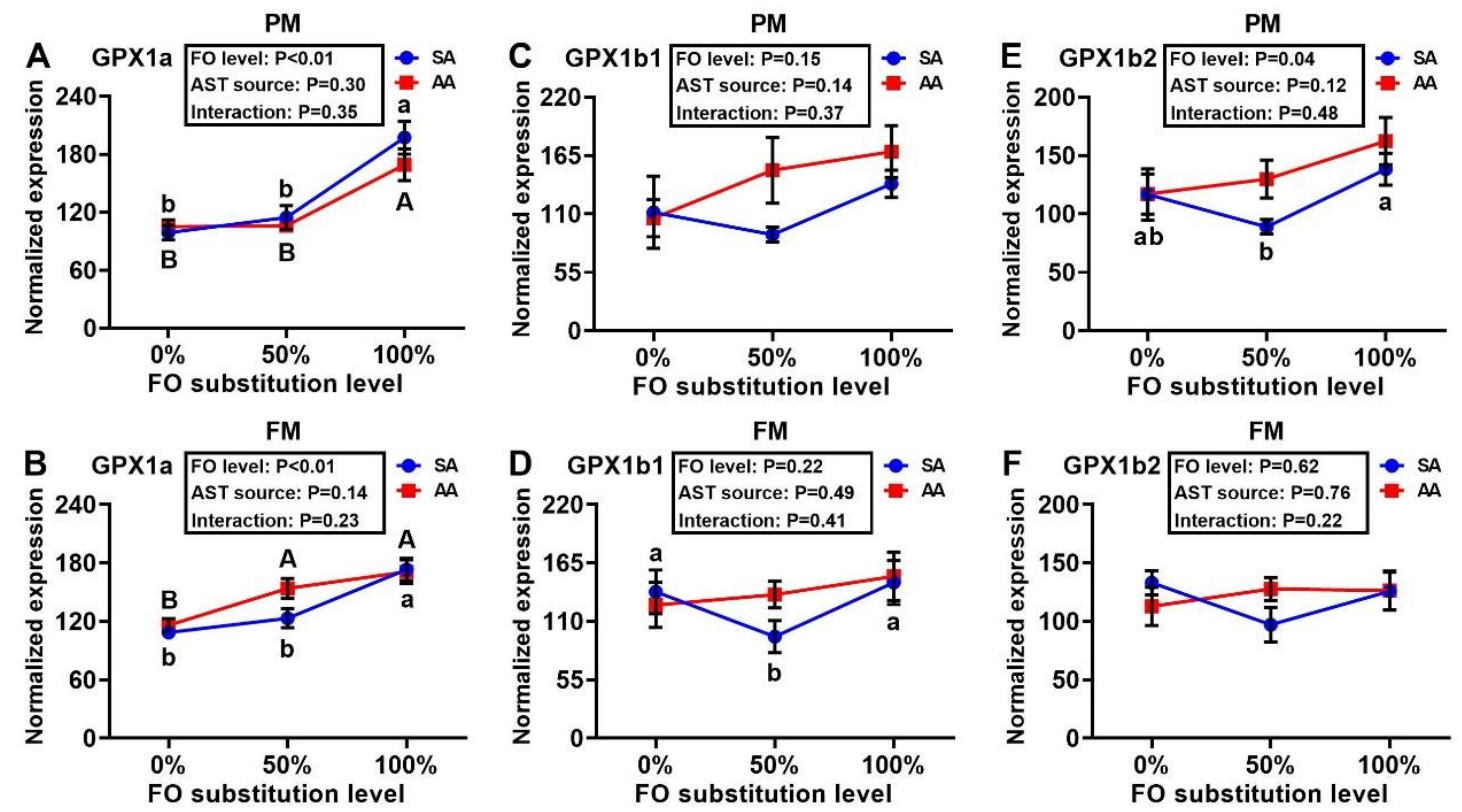

Figure 6. Effects of dietary fish oil substitution by DHA-rich microalgae and source of astaxanthin on hepatic mRNA levels of GPX1a (A,B), GPX1b1 (C,D), and GPX1b2 (E,F) of juvenile rainbow trout fed the plant meal- (PM, A,C,E) and fishmeal (FM, B,D,F)-based diets. Means labelled with different letters [lowercase (a, b), synthetic astaxanthin (SA) groups; uppercase (A, B), microalgae astaxanthin (AA) groups] are different between various fish oil substitutions $(p<0.05)$. The absence of different letters ( $a, b$ or A, B) between means indicates no significant differences. GPX: glutathione peroxidase. FO: fish oil. AST: astaxanthin. 

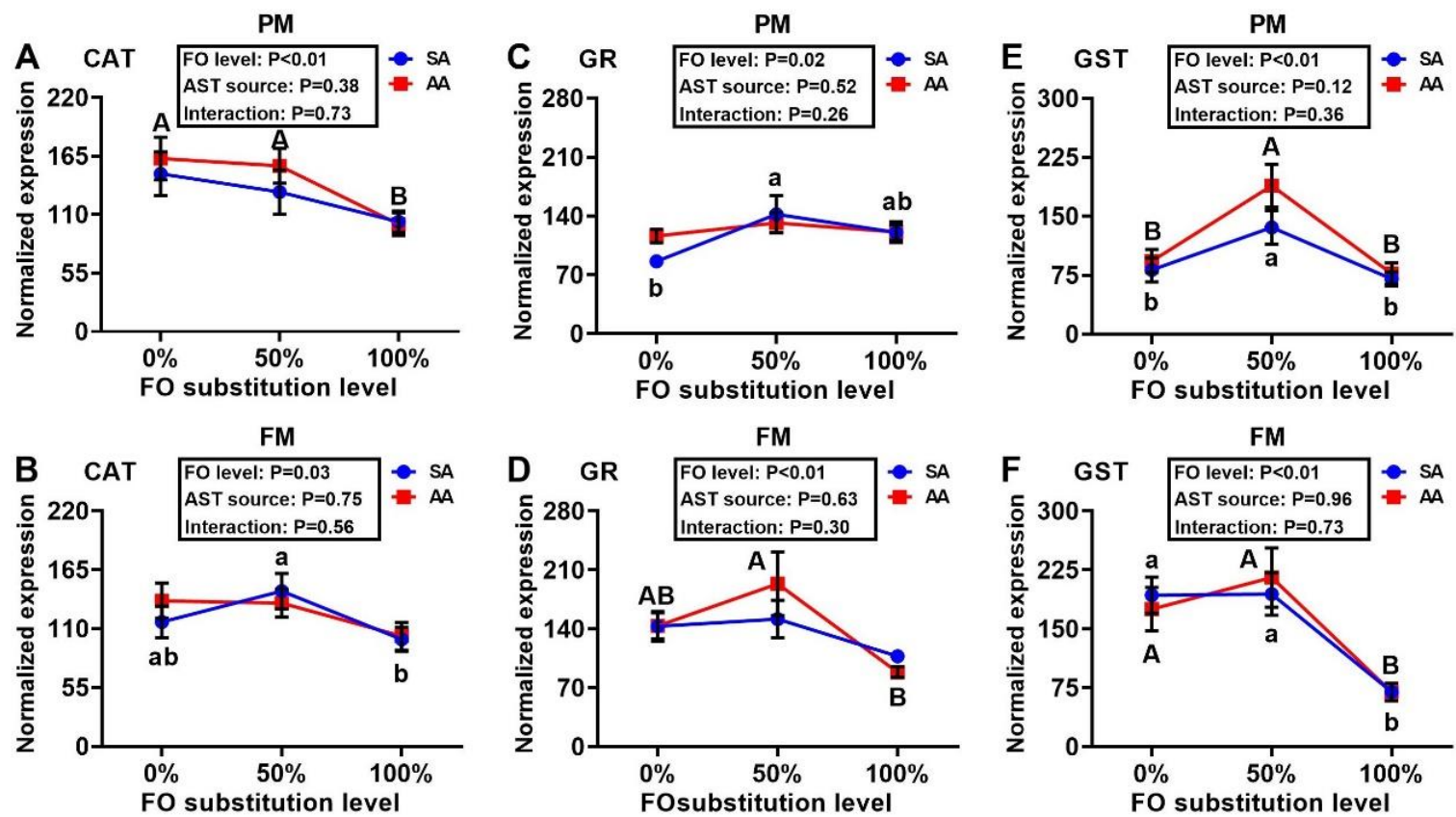

Figure 7. Effects of dietary fish oil substitution by DHA-rich microalgae and source of astaxanthin on hepatic mRNA levels of CAT (A,B), GR (C,D), and GST (E,F) of juvenile rainbow trout fed the plant meal- (PM, A,C,E) and fishmeal (FM, B,D,F)-based diets. Means labelled with different letters [lowercase $(a, b)$, synthetic astaxanthin (SA) groups; uppercase (A, B), microalgae astaxanthin (AA) groups] are different between various fish oil substitutions $(p<0.05)$. The absence of different letters (a, b or A, B) between means indicates no significant differences. CAT: catalase; GR: glutathione reductase; GST: glutathione S-transferase. FO: fish oil. AST: astaxanthin.

\subsection{Stepwise Regression Analyses}

In the first analysis of stepwise regression, the analyzed dietary concentrations of DHA [15] and AST were used as independent variables and the tissue concentrations of MDA and GSH and activities of GST, GPX, GR, and SOD were used as dependent variables (Table S3). The results indicated that the dietary DHA concentration was the remaining significant variable that positively affected activities of muscle GST $(R=0.74, p<0.05)$ and SOD $(R=0.91, p<0.05)$ and liver SOD $(R=0.82, p<0.05)$ in the PM diet series. Similarly, only the dietary DHA but not AST concentration showed a positive association with activities of muscle GST $(R=0.84, p<0.05)$ and GR $(R=0.74, p<0.05)$ and liver GPX $(R=0.78, p<0.05)$ in the FM diet series.

In the second analysis, the dependent variables were the same as in the first analysis whereas the independent variables included the tissue concentrations of DHA [15] and AST and liver mRNA levels of the eight antioxidant enzyme genes (Table S4). In the PM diet series, the muscle MDA concentration was negatively correlated with hepative GR mRNA level $(R=0.74, p<0.05)$, and the muscle GST $(R=0.84, p<0.05)$, GR $(R=0.83$, $p<0.05)$, and SOD $(R=0.96, p<0.05)$ activities were positively affected by hepatic mRNA levels of catalase. In comparison, liver MDA concentrations and activities of GR and SOD were positively affected $(R>0.77, p<0.05)$ by liver concentrations of GST or DHA [15]. Liver GSH concentrations and GPX and GST activities were positively affected $(R>0.75$, $p<0.05)$ by mRNA levels of three different antioxidant enzyme genes. In the FM diet series, muscle GSH concentrations and GST, GR, and SOD activities were affected $(R>0.75$, $p<0.05$ ) by hepatic mRNA levels of three antioxidant enzyme genes respectively or jointly. Liver GSH concentrations $(R=0.75, p<0.05)$ and GR activities $(R=0.97, p<0.05)$ were affected by liver concentrations of AST and DHA [15], respectively. Liver activites of the four antioxidant enzymes were affected $(R>0.90, p<0.05)$ by hepatic mRNA levels of four different antioxidant enzyme genes. 


\section{Discussion}

It is novel to show the main effects of FO substitution by DHA-rich microalgae and its interaction effects with the source of AST on tissue MDA and GSH concentrations and activities of GST, GPX, GR, and SOD. There were dose-dependent elevations of MDA in the liver of trout fed the SA diets with increasing levels of FO substitutions. As MDA is an end-product of lipid peroxidation, the rise in MDA implies accelerated oxidative stress [31]. In comparison, trout fed the AA diets maintained similar liver MDA concentrations across different levels of FO substitution, despite higher baseline values than those fed the SA diet at the $0 \%$ FO substitution. Likewise, the FO substitution largely suppressed activities of the assayed antioxidant enzymes in liver and (or) muscle with a few exceptions. The suppression was relatively stronger or more consistent with the GST and SOD rather than GPX and GR activities in either PM or FM diet series. The stepwise regression analyses also reinforced the importance of dietary DHA concentrations [15] (due to the FO substitution by microalgal DHA) in upregulating tissue activities of antioxidant enzymes. Previous studies also indicated that DHA enhanced antioxidative enzyme activities [32,33]. Structurally, DHA has a number of double bonds that are susceptible to oxidation [34]. Compared with the $50 \%$ and $100 \%$ FO substitutions, the $0 \%$ FO substitution diet contained a higher concentration of DHA [15] that might induce more oxidation reactions, resulting in upregulation of antioxidant enzymes to maintain the redox balance [35]. In contrast, the AST source showed little or no consistent effects on tissue GSH concentrations and antioxidant enzyme activities. This outcome was somewhat different from our expectations that intrinsic antioxidant defense [19] in tissues might be altered by or respond to supplemental SA and AA differently. In fact, supplemental AST was shown to enhance body antioxidant capacity of aquatic species [36-38] and mammals [39-41] in a number of studies, although the opposite was reported in other studies $[19,42-44]$ as a coordination between the intrinsic and extrinsic antioxidants [43]. However, there were strong positive correlations between the AST concentrations and the antioxidant enzyme activities and GSH concentrations in the muscle and (or) liver, despite variations with the diet treatments. This implies that once AST was absorbed from the diet and transported to tissues, it could exhibit greater antioxidant or redox-modulating potential. Because FO substitution downregulated the tissue AST deposition, part of its inhibition of antioxidant enzyme activities could be attributed to the resultant AST declines in the tissues. Therefore, the impacts of dietary AST source or concentration on tissue antioxidant enzyme activities and redox balance are not unilateral but multi-lateral.

Dietary AST source produced no significant differences in the mRNA abundances of the assayed antioxidant enzyme genes. Because the AST concentrations in the AA diets were lower than those of the SA diets, AA was presumably more functionally potent than SA on the same mass basis in regulating these genes. A previous study suggested that SA needed to be used at a rate 14-55 times greater than AA to obtain the equivalent antioxidant protection [7]. Likewise, FO substitution markedly decreased mRNA levels of SOD2 and CAT in the PM diet series and mRNA levels of GR and GST in the FM diet series. This could be partially attributed to declined AST concentrations by FO substitution, as AST was found to upregulate the expression of tissue antioxidant protein genes [36,37,45]. Yang et al. [46] suggested that AST could improve nuclear factor E2-related factor 2 (Nrf2)mediated endogenous antioxidant defense. Activation of the Nrf2 pathway enhanced GSH concentrations and gene expression of antioxidant enzymes such as GPX, GST, and GR [47,48]. Plausibly, Nrf2 might constitute a link between the tissue AST deposition and antioxidant enzyme responses in the present study. However, further studies are needed to investigate whether and how AST activates the Nrf2 pathway in trout. Intriguingly, in both FM and PM diet series, the 100\% FO substitution upregulated GPX1a expression compared with the $0 \%$ FO substitution, which was opposite to the GPX enzyme activity changes. It is plausible that upregulated mRNA abundance represented a compensatory response to the depressed GPX activity, which helped maintain the redox homeostasis. The stepwise regression showed that GPX1b1 and GPX1b2 were positively correlated with 
GPX and GST activities, whereas the GPX1a mRNA was rendered as the negative variable for activities of several antioxidant enzymes. These results reflect different responses and sensitivities of various GPX gene isoforms [49]. Similar effects of GPX1b1 and GPX1b2 may be attributed to their closer relationship of gene sequences compared with GPX1a [50]. Furthermore, the stepwise regression analyses indicated that the hepatic CAT and GR mRNA levels might be relevant biomarkers to reflect muscle antioxidant status in the PM diet series. This notion was supported by a negative correlation between the liver GR expression and muscle MDA concentrations and a positive correlation between liver CAT expression and muscle activities of GST, GR, and SOD. Notably, the muscle and liver AST and DHA concentrations [15] showed different correlations with antioxidant biomarkers from those with dietary AST and DHA concentrations. Dietary AST concentrations showed no association with GSH concentration or antioxidant enzyme activities in the muscle or liver, whereas liver AST concentration was positively correlated with the liver GSH concentration in the FM diet series. Dietary DHA concentration remained as a positive variable of many antioxidative enzymes; however, liver DHA concentration was shown as the positive factor of only hepatic GR activity in the FM diet series. These divergent effects indicate the complexity of regulation of redox status between extrinsic foods and intrinsic biological systems [51]. As for DHA, its oxidative potential varies with environment, such as in micelles, emulsion, cell membrane, or biological systems, and depends on the relative location of the lipid substrate and interaction of antioxidants and pro-oxidants [51]. It seems that the interaction of DHA and AST and the change in environment strengthened the correlations between the antioxidant enzymes and tissue AST concentrations but weakened such correlations with tissue DHA concentrations.

Our results indicate that the FO substitution inhibited the enrichment of AST in the liver and muscle. The inhibition was particularly evident in the muscle of fish fed the PM diet series where the muscle AST concentration in the 100\% FO substitution group dropped by as much as $89 \%$ (SA-fed) and $96 \%$ (AA-fed) compared with the respective $0 \%$ substitution groups. Although there was no clear reason to explain the difference in the sensitivities to the FO substitution and concentration changes in the diets between the two tissues, the muscle accumulated nearly ten-fold the amount of AST in the liver on the basis of per gram tissue. Maoka et al. [52] demonstrated that Salmonidae fish accumulated AST in the muscle in a species-specific fashion. Whereas integument tissues and gonads are the primary sites of carotenoid deposition in fish [52], liver seemed to have the highest enrichment of AST among several tissues of broiler chicks [19] and mice [53]. As a fat-soluble xanthophyll carotenoid, AST and lipids are closely related in absorption and metabolism [54]. A high level of lipids or unsaturated fatty acids is favorable to the incorporation of carotenoids [54-56]. Chimsung et al. [57] investigated the effects of carotenoids, plant sterols, fiber, cholesterol, and vitamin E on AST absorption in salmon and found that only cholesterol enhanced AST absorption. Seemingly, the lack of cholesterol in the microalgal DHA supplementation, in comparison with the FO [58], might have contributed to the decrease in AST absorption and deposition in the $100 \% \mathrm{FO}$ substitution groups. In a parallel study [15], we found that FO substitutions with DHArich microalgae in both PM and FM diet series decreased concentrations of one or more monounsaturated fatty acids, in agreement with the finding that the fillet concentration of astaxanthin was positively correlated to supplementary oil content of monounsaturated fatty acids in salmon [59]. Furthermore, the absorption and deposition of AST might also be affected by the differences in lipid composition at the different FO substitution levels [60].

Trout fed with SA had higher AST deposition in the liver and muscle than those fed with AA in both diet series. This pattern was similar to that found in other studies [61,62] and might be explained by higher concentrations or portions of free AST in SA than AA that could be accumulated directly in the tissues. In contrast, AA was supposed to contain various carotenoids aside from AST such as $\beta$-carotene, canthaxanthin, lutein, and echinenone [54] that require a series of conversions into AST [52]. Microalgal AST was reported to have multiple isomers and complex forms. The $\mathrm{Z}$ isomer was less efficiently 
deposited than the E isomers [5] and the esterified AST was less efficiently absorbed than the unesterified AST [63]. In addition, the thick cell walls of microalgae may impede the digestibility and absorption of the pigments by fish [64]. In line with these chemical form variations, we revealed different metabolic profiles of AA and SA in the liver. Future study is warranted to characterize the chemical structure and metabolic function of those detected new peaks.

\section{Conclusions}

Gene expressions and activities of major antioxidant enzymes were suppressed by FO substitution with DHA-rich microalgae in the liver and muscle of rainbow trout. The FO substitution also decreased the deposition of AST from either SA or AA. Whereas tissue AST concentrations were correlated with the intrinsic antioxidant enzyme activities, dietary source and (or) concentration of AST exerted no major or consistent effect on functional expression of antioxidant enzymes in the liver or muscle of trout. The FO and SA substitutions showed moderate interaction effects on the responses of redox status biomarkers in the tissues of trout, which varied with the major protein type (PM vs. FM) in the diets.

Supplementary Materials: The following are available online at https://www.mdpi.com/2076-3 921/10/1/16/s1, Table S1: Primer sequences for qPCR. Table S2: Correlations between astaxanthin concentrations and MDA and GSH concentrations and antioxidant enzyme activities in the muscle and liver of rainbow trout. Table S3: Stepwise regression analysis of tissue redox biomarkers as dependent variables and dietary AST and DHA concentrations as independent variables in rainbow trout. Table S4: Stepwise regression analysis of tissue redox biomarkers as dependent variables and tissue AST and DHA concentrations and antioxidant enzyme gene mRNA levels as independent variables in rainbow trout.

Author Contributions: X.G.L., B.M.C. and W.M.S. designed the experiment. K.W., B.M.C., M.P. and W.M.S. conducted all the experiments, the laboratory analysis and the data analysis. K.W. drafted the manuscript. X.G.L., B.M.C., M.P. and W.M.S. revised the manuscript. All authors have read and agreed to the published version of the manuscript.

Funding: This research was funded by the DOE MAGIC grant DE-EE0007091, USDA grant 201969012-29905, and the Cornell University Hatch grant NYC-127302.

Institutional Review Board Statement: The study was conducted according to the guidelines of the Declaration of Helsinki, and approved by the Cornell University Animal Care and Use Committee and the U.S. Fish and Wildlife Service (Protocol: Developing a new feed protein complex to replace fishmeal in fish farming, \#2017-0072, approved on 10-24-2017).

Informed Consent Statement: Not applicable.

Data Availability Statement: Data is contained within the article.

Acknowledgments: Lisa Radler at the National Center for Cool and Cold Water Aquaculture provided technical contributions for the gene expression analysis. Mention of trade names is provided solely for accuracy and does not imply endorsement by the federal government. The USDA is an equal opportunity employer and provider.

Conflicts of Interest: The authors declare no conflict of interest.

\section{References}

1. Setala, J.; Niukko, J.; Saarni, K. Fish Market Review 2016; Natural Resources Institute Finland (Luke): Helsinki, Finland, 2017.

2. Adeli, A.; Baghaei, F. Production and supply of rainbow trout in Iran and the world. World J. Fish Mar. Sci. $2013,5,335-341$.

3. Turchini, G.M.; Torstensen, B.E.; Ng, W.K. Fish oil replacement in finfish nutrition. Rev. Aquac. 2009, 1, 10-57. [CrossRef]

4. Perez-Velazquez, M.; Gatlin III, D.M.; González-Felix, M.L.; Garcia-Ortega, A.; de Cruz, C.R.; Juarez-Gomez, M.L.; Chen, K. Effect of fishmeal and fish oil replacement by algal meals on biological performance and fatty acid profile of hybrid striped bass (Morone crhysops $+\times$ M. saxatiliso'). Aquaculture 2019, 507, 83-90. [CrossRef]

5. Turck, D.; Castenmiller, J.; De Henauw, S.; Hirsch-Ernst, K.I.; Kearney, J.; Maciuk, A.; Pentieva, K. Safety of astaxanthin for its use as a novel food in food supplements. EFSA J. 2020, 18, e05993.

6. Koller, M.; Muhr, A.; Braunegg, G. Microalgae as versatile cellular factories for valued products. Algal Res. $2014,6,52-63$. [CrossRef] 
7. Capelli, B.; Bagchi, D.; Cysewski, G.R. Synthetic astaxanthin is significantly inferior to algal-based astaxanthin as an antioxidant and may not be suitable as a human nutraceutical supplement. Nutrafoods 2013, 12, 145-152. [CrossRef]

8. EFSA Panel on Additives and Products or Substances used in Animal Feed (FEEDAP). Scientific Opinion on the safety and efficacy of synthetic astaxanthin as feed additive for salmon and trout, other fish, ornamental fish, crustaceans and ornamental birds. EFSA J. 2014, 12, 3724. [CrossRef]

9. Davinelli, S.; Nielsen, M.E.; Scapagnini, G. Astaxanthin in skin health, repair, and disease: A comprehensive review. Nutrients 2018, 10, 522. [CrossRef]

10. Martinez-Delgado, A.A.; Khandual, S.; Villanueva-Rodríguez, S.J. Chemical stability of astaxanthin integrated into a food matrix: Effects of food processing and methods for preservation. Food Chem. 2017, 225, 23-30. [CrossRef]

11. Dominguez-Bocanegra, A.R.; Ponce-Noyola, T.; TorresMunoz, J.A. Astaxanthin production by Phaffia rhodozyma and Haematococcus pluvialis: A comparative study. Appl. Microbiol. Biotechnol. 2007, 75, 783-791. [CrossRef]

12. Sprague, M.; Walton, J.; Campbell, P.J.; Strachan, F.; Dick, J.R.; Bell, J.G. Replacement of fish oil with a DHA-rich algal meal derived from Schizochytrium sp. on the fatty acid and persistent organic pollutant levels in diets and flesh of Atlantic salmon (Salmo salar, L.) post-smolts. Food Chem. 2015, 185, 413-421. [CrossRef] [PubMed]

13. Betiku, O.C.; Barrows, F.T.; Ross, C.; Sealey, W.M. The effect of total replacement of fish oil with DHA-Gold ${ }^{\circledR}$ and plant oils on growth and fillet quality of rainbow trout (Oncorhynchus mykiss) fed a plant-based diet. Aquacult. Nutr. 2016, 22, 158-169. [CrossRef]

14. Belanger-Lamonde, A.; Sarker, P.K.; Ayotte, P.; Bailey, J.L.; Bureau, D.P.; Chouinard, P.Y.; Dewailly, E.; Leblanc, A.; Weber, J.P.; Vandenberg, G.W. Algal and vegetable oils as sustainable fish oil substitutes in rainbow trout diets: An approach to reduce contaminant exposure. J. Food Qual. 2018, 7949782. [CrossRef]

15. Zhu, S.L.; Portman, M.; Cleveland, B.M.; Magnuson, A.D.; Wu, K.; Sealey, W.; Lei, X.G. Replacing fish oil and astaxanthin by microalgal sources produced different metabolic responses in juvenile rainbow trout fed two types of practical diets. J. Anim. Sci. 2020, in press. [CrossRef]

16. Sommer, T.R.; D'Souza, F.M.L.; Morrissy, N.M. Pigmentation of adult rainbow trout, Oncorhynchus mykiss, using the green alga Haematococcus pluvialis. Aquaculture 1992, 106, 63-74. [CrossRef]

17. Lorenz, R.T.; Cysewski, G.R. Commercial potential for Haematococcus microalgae as a natural source of astaxanthin. Trends. Biotechnol. 2000, 18, 160-167. [CrossRef]

18. Tejera, N.; Cejas, J.R.; Rodriguez, C.; Bjerkeng, B.; Jerez, S.; Bolanos, A.; Lorenzo, A. Pigmentation, carotenoids, lipid peroxides and lipid composition of skin of red porgy (Pagrus pagrus) fed diets supplemented with different astaxanthin sources. Aquaculture 2007, 270, 218-230. [CrossRef]

19. Sun, T.; Yin, R.; Magnuson, A.D.; Tolba, S.A.; Liu, G.; Lei, X.G. Dose-dependent enrichments and improved redox status in tissues of broiler chicks under heat stress by dietary supplemental microalgal astaxanthin. J. Agric. Food Chem. 2018, 66, 5521-5530. [CrossRef]

20. Naguib, Y.M. Antioxidant activities of astaxanthin and related carotenoids. J. Agric. Food Chem. 2000, 48, 1150-1154. [CrossRef]

21. Ismail, A.; Bannenberg, G.; Rice, H.B.; Schutt, E.; MacKay, D. Oxidation in EPA-and DHA-rich oils: An overview. Lipid Tech. 2016, 28, 55-59. [CrossRef]

22. Lopez, A.B.; Van Eck, J.; Conlin, B.J.; Paolillo, D.J.; O’Neill, J.; Li, L. Effect of the cauliflower or transgene on carotenoid accumulation and chromoplast formation in transgenic potato tubers. J. Exp. Bot. 2008, 59, 213-223. [CrossRef] [PubMed]

23. Sowell, A.L.; Huff, D.L.; Yeager, P.R.; Caudill, S.P.; Gunter, E.W. Retinol, alpha-tocopherol, lutein/zeaxanthin, beta-cryptoxanthin, lycopene, alpha-carotene, trans-beta-carotene, and four retinyl esters in serum determined simultaneously by reversed-phase HPLC with multiwavelength detection. Clin. Chem. 1994, 40, 411-416. [CrossRef] [PubMed]

24. Breithaupt, D.E. Identification and quantification of astaxanthin esters in shrimp (Pandalus borealis) and in a microalga (Haematococcus pluvialis) by liquid chromatography-mass spectrometry using negative ion atmospheric pressure chemical ionization. $J$. Agric. Food Chem. 2004, 52, 3870-3875. [CrossRef] [PubMed]

25. Rohrle, F.T.; Moloney, A.P.; Osorio, M.T.; Luciano, G.; Priolo, A.; Caplan, P.; Monahan, F.J. Carotenoid, colour and reflectance measurements in bovine adipose tissue to discriminate between beef from different feeding systems. Meat Sci. 2011, 88, 347-353. [CrossRef]

26. Mcdonald, R.E.; Hultin, H.O. Some characteristics of the enzymatic lipid-peroxidation system in the microsomal fraction of flounder skeletal-muscle. J. Food Sci. 1987, 52, 15-21. [CrossRef]

27. Massey, V.; Williams, C.H., Jr. On the reaction mechanism of yeast glutathione reductase. J. Biol. Chem. 1965, $240,4470-4480$.

28. McCord, J.M.; Fridovich, I. Superoxide dismutase. An enzymic function for erythrocuprein (hemocuprein). J. Biol. Chem. 1969, 244, 6049-6055.

29. Mannervik, B.; Guthenberg, C. Glutathione transferase (human placenta). Meth. Enzymol. 1981, 77, $231-235$.

30. Flohe, L.; Gunzler, W.A. Assays of glutathione peroxidase. Meth. Enzymol. 1984, 105, 114-121.

31. Del Rio, D.; Stewart, A.J.; Pellegrini, N. A review of recent studies on malondialdehyde as toxic molecule and biological marker of oxidative stress. Nutr. Metab. Cardiovas. 2005, 15, 316-328. [CrossRef]

32. Duval, C.; Auge, N.; Frisach, M.F.; Casteilla, L.; Salvayre, R.; Negre-Salvayre, A. Mitochondrial oxidative stress is modulated by oleic acid via an epidermal growth factor receptor-dependent activation of glutathione peroxidase. Biochem. J. 2002, 367, 889-894. [CrossRef] [PubMed] 
33. Casanas-Sanchez, V.; Perez, J.A.; Fabelo, N.; Herrera-Herrera, A.V.; Fernandez, C.; Marin, R.; Gonzalez-Montelongo, M.C.; Diaz, M. Addition of docosahexaenoic acid, but not arachidonic acid, activates glutathione and thioredoxin antioxidant systems in murine hippocampal HT22 cells: Potential implications in neuroprotection. J. Neurochem. 2014, 131, 470-483. [CrossRef] [PubMed]

34. Iuchi, K.; Ema, M.; Suzuki, M.; Yokoyama, C.; Hisatomi, H. Oxidized unsaturated fatty acids induce apoptotic cell death in cultured cells. Mol. Med. Rep. 2019, 19, 2767-2773. [CrossRef] [PubMed]

35. Bauer, G.; Zarkovic, N. Revealing mechanisms of selective, concentration-dependent potentials of 4-hydroxy-2-nonenal to induce apoptosis in cancer cells through inactivation of membrane-associated catalase. Free Radic. Biol. Med. 2015, 81, 128-144. [CrossRef] [PubMed]

36. Zhang, J.; Liu, Y.J.; Tian, L.X.; Yang, H.J.; Liang, G.Y.; Yue, Y.R. Effects of dietary astaxanthin on growth, antioxidant capacity and gene expression in Pacific white shrimp Litopenaeus vannamei. Aquac. Nutr. 2013, 19, 917-927. [CrossRef]

37. Wang, H.; Dai, A.; Liu, F.; Guan, Y. Effects of dietary astaxanthin on the immune response, resistance to white spot syndrome virus and transcription of antioxidant enzyme genes in Pacific white shrimp Litopenaeus vannamei. Iran. J. Fish. Sci. 2015, 14, 699-718.

38. Liu, F.; Shi, H.; Guo, Q.; Yu, Y.; Wang, A.; Lv, F.; Shen, W.B. Effects of astaxanthin and emodin on the growth, stress resistance and disease resistance of yellow catfish (Pelteobagrus fulvidraco). Fish Shellfish Immun. 2016, 51, 125-135. [CrossRef]

39. Rao, A.R.; Reddy, A.H.; Aradhya, S.M. Antibacterial properties of Spirulina platensis, Haematococcus pluvialis, Botryococcus braunii micro algal extracts. Curr. Trends Biotechnol. Pharm. 2010, 4, 809-819.

40. Rao, A.R.; Sindhuja, H.N.; Dharmesh, S.M.; Sankar, K.U.; Sarada, R.; Ravishankar, G.A. Effective inhibition of skin cancer, tyrosinase, and antioxidative properties by astaxanthin and astaxanthin esters from the green alga Haematococcus pluvialis. J. Agric. Food Chem. 2013, 61, 3842-3851. [CrossRef]

41. Ghlissi, Z.; Hakim, A.; Sila, A.; Mnif, H.; Zeghal, K.; Rebai, T.; Bougatef, A.; Sahnoun, Z. Evaluation of efficacy of natural astaxanthin and vitamin $\mathrm{E}$ in prevention of colistin-induced nephrotoxicity in the rat model. Environ. Toxicol. Phar. 2014, 37, 960-966. [CrossRef]

42. Chien, Y.H.; Pan, C.H.; Hunter, B. The resistance to physical stresses by Penaeusmonodon juveniles fed diets supplemented with astaxanthin. Aquaculture 2003, 216, 177-191. [CrossRef]

43. Wang, Y.J.; Chien, Y.H.; Pan, C.H. Effects of dietary supplementation of carotenoids on survival, growth, pigmentation, and antioxidant capacity of characins, Hyphessobry concallistus. Aquaculture 2006, 261, 641-648. [CrossRef]

44. Pan, C.H.; Chien, Y.H.; Wang, Y.J. Antioxidant defense to ammonia stress of characins (Hyphessobrycon eques Steindachner) fed diets supplemented with carotenoids. Aquac. Nutr. 2011, 17, 258-266. [CrossRef]

45. Yang, Y.; Pham, T.X.; Wegner, C.J.; Kim, B.; Ku, C.S.; Park, Y.K.; Lee, J.Y. Astaxanthin lowers plasma TAG concentrations and increases hepatic antioxidant gene expression in diet-induced obesity mice. Brit. J. Nutr. 2014, 112, 1797-1804. [CrossRef]

46. Yang, Y.; Seo, J.M.; Nguyen, A.; Pham, T.X.; Park, H.J.; Park, Y.; Kim, B.; Bruno, R.S.; Lee, J. Astaxanthin-rich extract from the green alga Haematococcus pluvialis lowers plasma lipid concentrations and enhances antioxidant defense in apolipoprotein $\mathrm{E}$ knockout mice. J. Nutr. 2011, 141, 1611-1617. [CrossRef]

47. Harvey, C.J.; Thimmulappa, R.K.; Singh, A.; Blake, D.J.; Ling, G.; Wakabayashi, N.; Fujii, J.; Myers, A.; Biswal, S. Nrf2-regulated glutathione recycling independent of biosynthesis is critical for cell survival during oxidative stress. Free Radic. Biol. Med. 2009, 46, 443-453. [CrossRef]

48. Zhu, H.; Itoh, K.; Yamamoto, M.; Zweier, J.L.; Li, Y. Role of Nrf2 signaling in regulation of antioxidants and phase 2 enzymes in cardiac fibroblasts: Protection against reactive oxygen and nitrogen species-induced cell injury. FEBS Lett. 2005, 579, 3029-3036. [CrossRef]

49. Wischhusen, P.; Larroquet, L.; Durand, T.; Oger, C.; Galano, J.M.; Rocher, A.; Vigor, C.; Prabhu, P.A.J.; Veron, V.; Briens, M.; et al. Oxidative stress and antioxidant response in rainbow trout fry exposed to acute hypoxia is affected by selenium nutrition of parents and during first exogenous feeding. Free Radic. Bio. Med. 2020, 155, 99-113. [CrossRef]

50. Pacitti, D.; Wang, T.; Page, M.M.; Martin, S.A.M.; Sweetman, J.; Feldmann, J.; Secombes, C.J. Characterization of cytosolic glutathione peroxidase and phospholipid-hydroperoxide glutathione peroxidase genes in rainbow trout (Oncorhynchus mykiss) and their modulation by in vitro selenium exposure. Aquat. Toxicol. 2013, 130, 97-111. [CrossRef]

51. Miyashita, K. Paradox of omega-3 PUFA oxidation. Eur. J. Lipid Sci. Tech. 2014, 116, 1268-1279. [CrossRef]

52. Maoka, T. Carotenoids in marine animals. Mar. Drugs 2011, 9, 278-293. [CrossRef] [PubMed]

53. Showalter, L.A.; Weinman, S.A.; Osterlie, M.; Lockwood, S.F. Plasma appearance and tissue accumulation of non-esterified, free astaxanthin in C57BL/ 6 mice after oral dosing of a disodium disuccinate diester of astaxanthin (Heptax). Comp. Biochem. Physiol. C Toxicol. Pharmacol. 2004, 137, 227-236. [CrossRef] [PubMed]

54. Chien, Y.H.; Shiau, W.C. The effects of dietary supplementation of algae and synthetic astaxanthin on body astaxanthin, survival, growth, and low dissolved oxygen stress resistance of kuruma prawn, Marsupenaeus japonicus Bate. J. Exp. Mar. Biol. Ecol. 2005, 318, 201-211. [CrossRef]

55. Barbosa, M.J.; Morais, R.; Choubert, G. Effect of carotenoid source and dietary lipid content on blood astaxanthin concentration in rainbow trout (Oncorhynchus mykiss). Aquaculture 1999, 176, 331-341. [CrossRef]

56. Okada, Y.; Ishikura, M.; Maoka, T. Bioavailability of astaxanthin in Haematococcus algal extract: The effects of timing of diet and smoking habits. Biosci. Biotechnol. Biochem. 2009, 73, 1928-1932. [CrossRef] 
57. Chimsung, N.; Tantikitti, C.; Milley, J.E.; Verlhac-Trichet, V.; Lall, S.P. Effects of various dietary factors on astaxanthin absorption in Atlantic salmon (Salmo salar). Aquac. Res. 2014, 45, 1611-1620. [CrossRef]

58. Conchillo, A.; Valencia, I.; Puente, A.; Ansorena, D.; Astiasaran, I. Functional components in fish and algae oils. Nutr. Hosp. 2006, 21, 369-373.

59. Bjerkeng, B.; Hatlen, B.; Wathne, E. Deposition of astaxanthin in fillets of Atlantic salmon (Salmo salar) fed diets with herring, capelin, sandeel, or Peruvian high PUFA oils. Aquaculture 1999, 180, 307-319. [CrossRef]

60. Clark, R.M.; Yao, L.; She, L.; Furr, H.C. A comparison of lycopene and astaxanthin absorption from corn oil and olive oil emulsions. Lipids 2000, 35, 803-806. [CrossRef]

61. Choubert, G.; Heinrich, O. Carotenoid pigments of the green alga Haematococcus pluvialis: Assay on rainbow trout, Oncorhynchus mykiss, pigmentation in comparison with synthetic astaxanthin and canthaxanthin. Aquaculture 1993, 112, 217-226. [CrossRef]

62. Pan, C.H.; Chien, Y.H. Effects of dietary supplementation of alga Haematococcus pluvialis (Flotow), synthetic astaxanthin and $\beta$-carotene on survival, growth, and pigment distribution of red devil, Cichlasoma citrinellum (Gunther). Aquac. Res. 2009, 40, 871-879. [CrossRef]

63. Storebakken, T.; Foss, P.; Schiedt, K.; Austreng, E.; Liaaen-Jensen, S.; Manz, U. Carotenoid diets in salmonids: IV. Pigmentation of Atlantic salmon with astaxanthin, astaxanthin dipalmitate and canthaxanthin. Aquaculture 1987, 43, $185-193$.

64. Johnson, E.A.; An, G.H. Astaxanthin from microbial sources. Crit. Rev. Biotechnol. 1991, 11, 297-326. [CrossRef] 